Cinémas

Revue d'études cinématographiques

Journal of Film Studies

\title{
Stage Actors and Modern Acting Methods Move to Hollywood in the 1930s
}

\section{L'arrivée à Hollywood, dans les années 1930, des acteurs de théâtre et des techniques de jeu modernes}

\section{Cynthia Baron}

Volume 25, numéro 1, automne 2014

L’acteur entre les arts et les médias

URI : https://id.erudit.org/iderudit/1030232ar

DOI : https://doi.org/10.7202/1030232ar

Aller au sommaire du numéro

Éditeur(s)

Cinémas

ISSN

1181-6945 (imprimé)

1705-6500 (numérique)

Découvrir la revue

Citer cet article

Baron, C. (2014). Stage Actors and Modern Acting Methods Move to Hollywood in the 1930s. Cinémas, 25(1), 109-129. https://doi.org/10.7202/1030232ar
Résumé de l'article

Dans cet article, l'auteure s'intéresse aux facteurs qui, dans les années 1930 aux États-Unis, ont amené de nombreux acteurs issus du théâtre à livrer, sur la scène aussi bien qu'à l'écran, des performances basées sur les principes du jeu théâtral moderne (articulés par Stanislavski, enseignés à l'American Academy of Dramatic Arts de New York ou décrits dans les manuels d'art dramatique) pour s'adapter à l'arrivée du parlant, puis à l'industrialisation du cinéma sonore, qui ont profondément bouleversé les perspectives d'emploi à Broadway et les méthodes de production à Hollywood. Pour illustrer certains aspects de la conception que les acteurs formés aux arts de la scène se faisaient du jeu moderne à cette époque exceptionnelle de l'histoire américaine des arts du spectacle, l'auteure analyse une scène jouée par Spencer Tracy dans Captains Courageous (Capitaines courageux, Victor Fleming, 1937) et une scène du film The Guardsman (L'officier de la garde, Sidney Franklin, 1931) interprétée par Alfred Lunt et Lynn Fontanne. 


\title{
Stage Actors and Modern Acting Methods Move to Hollywood in the 1930s
}

\section{Cynthia Baron}

\begin{abstract}
In this article, the author considers factors in commercial 1930s American theatre and film which led to the unusual circumstance of many stage-trained actors employing ostensibly theatrical acting methods to respond effectively to the challenges and opportunities of industrial sound film production. The author proposes that with American sound cinema fundamentally changing employment prospects on Broadway and Hollywood production practices, the 1930s represent a unique moment in the history of American performing arts, wherein stage-trained actors in New York and Hollywood developed performances according to principles of modern acting articulated by Stanislavsky, the American Academy of Dramatic Arts in New York and the acting manuals written by theatre-trained professionals and used by both stage and screen actors. To illustrate certain aspects of the era's conception of modern acting, the author analyzes a scene from Captains Courageous (Victor Flemining, 1937) with Spencer Tracy and a scene from The Guardsman (Sidney Franklin, 1931) with Alfred Lunt and Lynn Fontanne.
\end{abstract}

In the 1930s, methods for building modern, naturalistic performances migrated from Broadway to Hollywood due to concrete industrial developments. These changes become especially legible when one considers them from the pragmatic perspective of the actors who sought to employ their craft during the period when Hollywood successfully challenged Broadway for ascendency in the business of American performing arts. One vital point to consider is that after Broadway productions rose to a peak of 288 in the landmark 1927-28 season, productions declined each subsequent year, until there were just 80 in 194041. ${ }^{1}$ The concomitant, radical drop in theatrical work for 
American actors led to the strange situation in which more than "two-thirds of the actors under contract with major studios" in the 1930s had theatre experience and/or training at an institution designed for theatre actors (Clark 1995, p. 112). Significantly, these theatre expatriates often based their view of modern acting ${ }^{2}$ on the work of stage rather than screen stars; for example, "the most admired and celebrated actresses of their time" were Broadways stars such as Pauline Lord, Katharine Cornell, Ruth Chatterton and Lynn Fontanne (Wilson 2013, p. 92).

A second crucial factor to consider is that during this massive relocation of actors trained in methods of modern acting, performers working in Hollywood found that their (theatrical) methods for building performances were well suited to sound cinema's "regimented system of preparation and production," which had replaced silent era practices where directors often "ruled not only the set but also the entire process" (Schatz 2010, pp. 105, 36). For actors, Hollywood sound film production meant that the people they worked with to prepare their performances were often different from the people on set: drama coaches helped them hone their abilities to analyze scripts, and dialogue coaches aided in dramatic analysis of specific scenes, yet once actors arrived on set, they worked with directors who often simply identified ways for actors to adjust their physical and vocal expression to suit the requirements of individual shots (Baron 1999). The demands and opportunities of Hollywood sound production proved to be a good match for actors who had been trained to develop characterizations through independent script analysis; Hollywood's widespread use of the assemblyline system of production ensured that scripts were available for analysis in advance of shooting (Schatz 2010, p. 70), and actors' individual preparation was a necessity because directors could no longer coach actors during a take (Bordwell, Staiger and Thompson 1985, pp. 117-20, 151).

As the author has argued elsewhere, the transition to sound brought with it a reassessment of stage and screen acting (Baron 1999). Whereas practitioners in the 1920 s found that "screen acting had become an art in itself" (Klumph 1922, p. 104), the 
requirements of industrial sound cinema production led stagetrained actors to see more parallels than contrasts between stage and screen. Emphasizing the connections between acting in theatre and film during the studio era, American Academy of Dramatic Arts graduate Hume Cronyn (1949, p. 46) noted, "The difference between acting for the screen and acting for the stage is negligible and the latter is, despite the exceptions, the best possible training for the former." He explained that training in modern stage acting was ideal for working in sound cinema because the actor's "business, as in theatre, remains with the character he is to play and this will require his full powers of concentration."

In the 1930s, stage-trained actors who found employment in Hollywood continued to develop their characterizations the same way they had when working in theatre. They saw the subsequent process of executing performances as involving specific adjustments to the venue or medium. Articulating the era's prevailing view, stage-trained actress Bette Davis (1946, p. 634) explains: while "it is axiomatic that a screen actor works in a medium that has its own, its special technical demands ... this is not a qualitative distinction, it is merely quantitative." Amplifying this, she observes: stage and screen actors "work with the same tools. Our craft requires slight modification in them, that is all." To provide a gloss on the points made by Cronyn and Davis, one could say that in the 1930s stage-trained actors working in Hollywood used individual script analysis and sometimes worked with dialogue directors to identify and develop characters' given circumstances, objectives and dramatic actions. During performances, their adjustments did not involve creating the more emphatic physical and vocal choices necessary to communicate with audiences in theatres of various sizes, but instead involved adjustments to expressions that were calibrated to suit specific framing and recording situations. Working in theatre or film in the 1930s, stage-trained actors understood they were expected to have mastered physical and vocal technique, so as to embody characters different from themselves (McTeague 1993, p. 65). Most importantly, their performances were designed to serve the demands of the script; teachers of 
modern acting "emphasized the fact that the play was supreme and that the playwright was the final arbiter of the characters" (p. 52).

As these observations suggest, the account in this essay, designed to complement other work by the author, ${ }^{3}$ departs from the more familiar histories of Method acting ${ }^{4}$ in recognizing that methods of modern acting spread throughout the profession after the coming of sound. The mass exodus from Broadway fostered the dissemination of these methods, which included an emphasis on dramatic analysis to determine characters' needs and reactions. While publicity surrounding the Actors Studio, established in 1947, suggested that acting on Broadway and in Hollywood in the 1930s was unscientific, unsystematic and based on ad hoc remedies, documents of the period reveal that modern acting's emphasis on actors portraying characters as found in the script meant that the era's acting principles were closely aligned with Stanislavsky's System (Carnicke 2009). These methods were integral to the training program at the American Academy of Dramatic Arts, and it is possible to see those principles applied in a scene with one of its graduates, Spencer Tracy (1900-1967). To further explore the type of performances that emerged from actors' application of these methods, the essay considers a scene that functions essentially as an archival record of theatrical performances by Alfred Lunt (1892-1977) and Lynn Fontanne (1887-1983), Broadway stars who exemplified the era's vision of modern acting.

\section{Modern Acting Methods at the American Academy of Dramatic Arts}

In the 1930 s, scores of actors began their careers on Broadway, but due to dwindling employment options in theatre turned to acting in Hollywood films. The list of theatre-trained actors who moved to Hollywood includes Humphrey Bogart, Katharine Hepburn, Paul Muni, Claudette Colbert, Clark Gable, Miriam Hopkins, Fredric March, Cary Grant and others (Wilson 1973, p. 400). Spencer Tracy, in the elite group of actors who have received two or more Oscars for Best Actor, appeared in Broadway productions such as Yellow (1926-27), 
Conflict (1929), The Big Shot (1929) and The Last Mile (1930), and was one of the many actors who left Broadway for Hollywood. Tracy is also one of the many players who attended the American Academy of Dramatic Arts, established in 1884 (prior to the founding of the Moscow Art Theatre in 1897). ${ }^{5}$ Because the Academy, which has had campuses in New York and Los Angeles since 1974, has trained several eventual film stars, it has been referred to as the "Cradle to the Stars"; a "sample from the first half of its history includes Edward G. Robinson and William Powell (1913), Thelma Ritter (1922), Spencer Tracy and Pat O'Brien (1923), Agnes Moorehead and Rosalind Russell (1929), Hume Cronyn (1934), Kirk Douglas (1941), Lauren Bacall (1942) and Colleen Dewhurst (1947)" (Raymond 2009, p. 6).

In the 1930s, the theatre-focused institution became an adjunct to the film industry by training actors who came to Hollywood with experience and recognized credentials. Making a clear break with the "imitative method of 'coaching' for the stage," the Academy's curriculum was initially developed by founder Franklin Haven Sargent (1856-1923), a Harvard University speech professor (1884, p. 475). During Sargent's tenure as head of the Academy until 1923, he continually updated the program in collaboration with Charles Jehlinger (1866-1952), "who was in the first graduating class of the Academy and subsequently taught there for nearly forty years" (McTeague 1993, p. 52). Jehlinger, who led the Academy from 1923 until his death in 1952, "shunned publicity" and was "virtually unknown outside of theatrical circles"; he was, however, "regarded by thousands of friends and former students as the most outstanding teacher of acting in the twentieth century" (anonymous 1952). By the end of his career, colleagues believed that the "standards of perfection and imagination he set for his pupils helped raise the level of American acting" (anonymous 1952).

An interview with Sargent reveals that he revised the program sometime around 1914 to facilitate an actor's abilities to "create through his imagination, intellect and feeling 'a character, a living human being'” (McTeague 1993, p. 51). ${ }^{6}$ Notes from 
Jehlinger's courses show that from the teens forward, his instruction provided students with tools to create performances with crafted units of actions that revealed characters' needs and reactions. As noted in an Academy pamphlet, according to Jehlinger, performances should be so securely grounded in the imaginative reality of characters' interactions that actors would "never change thought, theme or mood until something occurs to cause that change" (Gould 1958, p. 2). Even before the turn of the century, however, Sargent had introduced modern methods of acting preparation such as improvisation, designed to stimulate actors' imaginations, and life study, which enhanced their abilities to observe people and the world around them (McTeague 1993, pp. 83-85). Early on, courses in dramatic analysis sought to develop students' "'creative imagination' through the analysis of character and situation" (p. 86). As Jehlinger presented methods of modern acting, Academy students learned that actors must accept the truth of the play and the characters without reservation or qualification. He explained: "The character you portray must be you. But it isn't you. It is you as the character in the situation created by the author. . . . Every character has a heart, brain, and soul. You are the servant of the character; the character is not your servant. . . You must live with [your characters], study their attitudes toward various other characters in the play, their habit of thinking and living" (Gould 1958, pp. 1-3).

Spencer Tracy learned to approach performances according to these principles when he studied at the Academy in 1922 and 1923. His courses included dramatic analysis, life study, vocal interpretation and pantomime ${ }^{7}$ (Curtis 2011, p. 69). In Tracy's second year, he studied primarily with Jehlinger. Essentially quoting the Gould pamphlet that contains Jehlinger's views on modern acting, Tracy biographer James Curtis (2011, p. 70) explains that in Tracy's second year he learned that the "actor was the servant of the character ... and it was up to the character to run things, to make the performance inevitable." Tracy learned that dramatic analysis of the script required an actor to exercise his or her investigative and analytic abilities; by comparison, during performance an actor's thoughts and feelings "must 
correspond with those of the character he is portraying" (McTeague 1993, p. 62). Tracy has noted that he learned how to create modern, natural and seemingly spontaneous performances through his training at the Academy. As he explains, "I shall always be grateful to the American Academy for what I was taught there-by Mr. Jehlinger and the other teachers-the value of sincerity and simplicity" in performance, "unembellished" for the audience (Curtis 2011, p. 73). ${ }^{8}$

A scene with Tracy in Captains Courageous (Victor Fleming, 1937) arguably reveals Jehlinger's view that modern acting requires actors to think and feel as the character, to "surrender to the imaginative reality of the moment," and "never change thought, theme or mood until something occurs to cause that change" (McTeague 1993, p. 63; Gould 1958, p. 2). Captains Courageous centres on a seasoned Portuguese fisherman named Manuel (Tracy), whose troubles begin after he saves a young aristocrat named Harvey (Freddie Bartholomew) from drowning. After the boat's fishing catch is far below expectation, Manuel is assigned the difficult task of getting Harvey to do work onboard, which will, according to fishing superstition, end the bad luck he has brought to the ship. Tracy's performance conveys the series of actions Manuel uses to persuade Harvey to clean the deck. Harvey presents a series of obstacles to that objective; he is determined to get the dinner to which he feels entitled as a member of the upper class. (To differentiate the actors' performances from the characters' interactions, the present description refers to performance details that Tracy and Bartholomew use to communicate the thoughts and feelings of Manuel and Harvey.)

Tracy conveys that Manuel is very determined to achieve his goal in that he initiates the confrontation with Harvey in the scene's first unit of action; he also communicates Manuel's keen awareness of the characters' contrasting social status. Using calm, casual and implicitly deferential physical and vocal expression, Tracy shows audiences (unobtrusive onlookers) that Manuel would like to simply lure Harvey into working. Manuel tells Harvey how good his own supper was that night; he embellishes that point by cheerfully eating a piece of raisin 
bread left over from his dinner. Bartholomew shows that Harvey will not be won over by such a simple tactic; he stands rigid, refusing to work. To show Manuel's irritated response to Harvey's stubbornness, Tracy moves quickly into the second unit of action as his character busies himself with hanging a light on deck. Harvey resists Manuel's implicit demand that he also start working; he quietly pleads with Manuel to sneak him some food. Harvey's continued resistance prompts Manuel to use threatening tactics. To communicate that shift, in the third unit of action Tracy shouts; Manuel belittles the boy, loudly enough for his fellow crew members to hear. Harvey stands his ground, still refusing to work.

With the players crafting their performances according to the principles of modern acting articulated by Jehlinger, Stanislavsky and other early twentieth-century acting professionals, Harvey's resistance to the threatening tactic prompts Manuel to use an inducing action; that shift reflects Jehlinger's insight that actors should "never change thought, theme or mood until something occurs to cause that change" (Gould 1958 , p. 2). Thus, in the fourth unit of action, Tracy's gentle, free-flowing physical and vocal expression shows that Manuel is willing to give Harvey a big reward (five cents) if Harvey will clean the deck. Harvey counters by promising to give Manuel what he sees as a big reward; mistakenly thinking that a huge sum would matter in the isolated environment of the fishing boat, Harvey promises to pay Manuel $\$ 10,000$ if he will take him to New York in one of the small boats stacked on deck.

Harvey's irrelevant high-society tactic to control the confrontation propels Manuel into his next action. To convey Manuel's earthy resolve, Tracy uses relaxed, free-flowing movements as Manuel gently induces Harvey to join him in cleaning the deck. Harvey resists; Bartholomew conveys this by standing firmly but quietly in place. In response, in the sixth unit of action Tracy embodies Manuel's use of a threatening tactic, gruffly demanding to know if Harvey is going to work. Harvey holds his ground. The two characters have reached a standoff: there is nothing Manuel can do to get Harvey to work and nothing Harvey can do to get supper without working. 
Yet Tracy shows Manuel's superior position in this situation in the seventh unit of action. To communicate this reversal of social status, Tracy calmly turns his attention to cleaning the deck, thus conveying Manuel's threatening tactic of concluding the conversation. To match the raised stakes, Harvey lets a small boat down into the water. Bringing the confrontation into its final stages in the eighth unit of action, Tracy embodies Manuel's decision to overpower Harvey as he calmly picks Harvey up by his collar. Bartholomew communicates Harvey's resistance by thrashing about in an attempt to get away. To convey Manuel's confidence in his control of the situation, Tracy smiles when he sees Bartholomew begin to cry.

In the ninth unit of action, with Harvey completely overpowered, Manuel helps Harvey fulfill his end of the bargain. To convey that idea, Tracy cups Bartholomew's hands around a fish head and together they throw it over the side of the boat. With this token gesture signifying that Manuel has been victorious in this battle of wills, Tracy uses another inducing tactic in the scene's final unit of action as Manuel gently tells Harvey that he can have supper.

Tracy's performance reveals that he has analyzed the scene in advance so that Manuel's objective is clear to audiences and the actions reveal Manuel's thought process. By crafting the series of legible actions, Tracy makes the scene engaging for audiences as they watch to see how Manuel will deal with Harvey's resistance. His performance seems simple and unembellished because he has aligned his thoughts and feelings with the character as Jehlinger would require.

\section{Heightened Awareness of Acting Principles in a Time of Changing Employment Options}

The development of sound cinema, and the concomitant drop in the number of theatrical productions, created what one could call a Broadway diaspora, which widened the influence that Broadway stars had on actors working in Hollywood in the 1930s. Hollywood's rising and Broadway's falling fortunes also created an environment in which acting methods and principles became more clearly articulated. As the number of theatrical 
productions continued to decline in the 1930s, studio executives realized that the training grounds for actors skilled in the type of independent script that led to natural, spontaneous and modern performances had been exhausted. To shore up the supply of actors able to work efficiently in the assembly-line film production system, the studios hired theatre-trained drama coaches to train young actors and theatre-trained dialogue directors to work with individual actors on specific parts. They set up drama schools on the studio lots and developed close working relationships with institutions such as the American Academy of Dramatic Arts and the Pasadena Playhouse, and later the Actors' Laboratory in Hollywood formed by Group Theatre members and the School of Dramatic Art led by Moscow Art Theatre expatriate Maria Ouspenskaya (Baron 1999).

These production conditions, combined with the era's aesthetic values that placed a priority on realistic dramatic performances, led to the wide circulation and application of methods and principles described in the acting-directing manuals of the period. The manuals that articulated the concepts central to modern acting include: Acting: The First Six Lessons (1933) by Moscow Art Theatre expatriate Richard Boleslavsky (18891937); Modern Acting: A Manual (1936) authored by faculty at the University of Washington, including Sophie Rosenstein (1907-1952), who would later establish the drama schools at Warner Bros. and Universal; and General Principles of Play Directions (1943) by Pasadena Playhouse head Gilmor Brown (1886-1960). The acting methods and principles integral to stage and screen performances in the 1930s were also published in volumes such as Modern Acting: A Guide for Stage, Screen and Radio (1940) by long-time drama coach and dialogue director Josephine Gable Dillon (1884-1971), and Motion Picture Acting (1947) by Lillian Albertson (1881-1962), who started her acting career on Broadway and later worked as a dialogue director at Paramount and RKO.

While it is well known that Lee Strasberg, Stella Adler and Sanford Meisner drew on aspects of Stanislavsky's work to develop formulations of the Method, earlier applications of Stanislavsky's System are often overlooked. Thus, it is useful to 
note that acting professionals such as Lillian Albertson also circulated the methods of modern acting developed by Jehlinger and Stanislavsky. Albertson, who appeared in Broadway productions such as Paid in Full (1908) and The Devil's Garden (1915-16), turned to directing theatre productions on the West Coast in the 1920s. Her manual, published in 1947 from notes she had assembled during her long career in theatre and film, echoed Jehlinger's and Stanislavsky's emphasis on script analysis as the starting point for actors. Like other American practitioners who formulated the principles of modern acting, Albertson characterized script analysis the way Stanislavsky did-as intellectual analysis designed to locate: a character's given circumstances in each scene; a character's objective in each scene; the actions a character uses to reach his/her objective in a scene; and the units of action that reflect the series of actions or tactics he/she uses to achieve that objective. As Albertson (1947, p. 65) explained, actors must analyze a script by focusing on given circumstances and objectives, constantly asking: "What made this person feel the way he or she does, and do the things they do?" She amplified this point, explaining that detailed script analysis is what made it possible for actors to create a mental notebook of images and synthetic memories they could then open and close at will during performances (p. 63).

Like other stage-trained acting professionals of the period, Albertson used theatre actors as models for film acting. In her work with Hollywood actors, she proposed that performances by certain stage actors epitomized the natural but structured qualities of modern acting achieved when players train their bodies and voices, study the world around them and engage in thorough preparation by establishing the character's circumstances, objectives and actions for each scene. Identifying a handful of exemplary actors, Albertson (1947, p. 82) described Sarah Bernhardt as "the most superb player [she had] ever seen." She highlighted the work of Minnie Maddern Fiske and Holbrook Blinn; she wished that all actors "had the privilege of seeing John Barrymore in 'Hamlet"; and said Ethel Barrymore was an actress screen actors should study (pp. 82, 85). She described Helen Hayes and Katharine Cornell as "gifted 
actresses of the theater" whose performances warranted particular study by actors working in film (p. 85).

\section{Archival Record of Modern Acting}

Albertson (1947, p. 109) also used a scene from the 1936 stage production of Idiot's Delight (Robert E. Sherwood) made famous by Alfred Lunt and Lynn Fontanne to illustrate ways that film actors should prepare for performance. Albertson's reference to their work makes sense, in that Lunt and Fontanne were leading actors on Broadway from the 1920s to the 1950s. Their roles in the 1924 Theatre Guild production of The Guardsman (Ferenc Molnár) secured their status as Broadway stars. Their performances in productions such as Noël Coward's provocative comedy Design for Living, which opened in 1933 at the Ethel Barrymore Theatre in New York, highlighted the couple's grace, elegance and modern wit. Lunt and Fontanne were also models for the era's stage and screen actors, and mentors in an apprenticeship system that helped young performers create naturalistic performances grounded in extensive rehearsal and thorough attention to the craft of acting (Bosworth 2007, pp. 77-101). With a reputation as "the arch perfectionists of the theatre," the husband and wife team were known for their use of life study and exhaustive script analysis, and for their modern stage performances that featured dovetailed dialogue and physical intimacy (Funke and Booth 1961, p. 41).

From the Lunts' perspective, modern acting required hours of rehearsal, and complex interpretation of characters could only emerge from script analysis, as defined by Jehlinger and Stanislavsky, that sought to "give life to what the playwright has written" (Funke and Booth 1961, p. 51). Mastery of one's physical and vocal instrument was essential to effectively embody characters; the development of each characterization required new research and life study. Echoing Jehlinger and Stanislavsky, Fontanne explained that to create a modern, natural and seemingly spontaneous performance "you imagine yourself [to be] the person that the author has written and you sink yourself into that" (Funke and Booth 1961, p. 54). 
Lunt and Fontanne agreed to appear in only two films, Stage Door Canteen (Frank Borzage, 1943), a WWII revue film to support American troops, and The Guardsman (Sidney Franklin, 1931), which allowed them to document their roles in the 1924 stage production that had secured their position as Broadway's leading acting team. Despite the film's commercial success, its critical acclaim (Lunt and Fontanne were both nominated for Academy Awards) and the fact that the Lunts were given some control over the production, before and after the production they had no interest in Hollywood stardom, preferring instead to continue their work in theatre (Brown 1986, pp. 216-21).

The Guardsman is about a newly married couple. The wife's moody behaviour makes her husband believe she no longer loves him. To test his wife's fidelity, the husband woos her with flowers, notes and visits to their apartment, all in the guise of a Russian officer, the kind of man he thinks she fancies. The wife accepts the Guardsman's advances because the husband gives himself away in their first meeting. The husband, however, believes that his performance as the Russian officer is so great that even his wife does not suspect the truth. The amusing complication is that both the husband and the wife are accomplished and egotistical actors.

Having determined that his wife will be unfaithful to him, the husband costumes himself for a final confrontation with the woman he loves. The scene reveals the performers' attention to craft as their intense preparation allowed them to dovetail apparently overlapping dialogue. The scene also illuminates the actors' ability to structure the scene into units of action that are marked by shifting emphasis and resolution; their performances thus reflect Jehlinger's view that actors must think and feel as their characters, to the point that they would "never change thought, theme or mood until something occurs to cause that change" (Gould 1958, p. 2).

The couple's final confrontation scene begins with Fontanne's character sitting in the living room of the couple's apartment, seemingly absorbed in reading. Lunt, who had been dressed as the husband moments before, comes into the room dressed as the Russian officer. He crosses the room to stand at the back of 
the wife's chair. He carries a prop knife. Fontanne registers surprise and a bit of alarm when Lunt intones: "Have you prayed tonight, Desdemona?" However, a point-of-view shot of Lunt looming above Fontanne defuses the threat: the wife and the audience see that his makeup is hastily done, and so he looks more comical than sinister. Fontanne shows the audience and the husband that the wife is determined to play the scene as a comedy. She laughs, then comfortably and casually reaches up toward Lunt, who then conveys the husband's resistancedetermined to stick with his scenario, he gruffly demands that she explain why she is laughing, then grabs her arm and comes around the chair to face her.

In the next unit of action, however, Lunt communicates the husband's despair that his wife has "ruined his scene." Still holding Fontanne's arm, Lunt drops to his knees. The husband begs his wife to say she had never recognized him. She resists, but gently: in a medium shot that suggests the close bond between husband and wife, Fontanne softly pushes Lunt away as she says, "Of course I knew." With Lunt at her knees, Fontanne initiates the next unit of action. She straightens herself, sits back in her chair, and to convey the wife's response, mockingly explains precisely when the wife had determined that her husband was the Russian officer and had thus decided to beat him at his own game by playing along.

In response to her mocking, the husband fights back. To show the husband's need to keep the scene a tragedy, Lunt grabs Fontanne's wrists in response to the wife's line that it was difficult not to laugh in the husband's face. Fontanne remains still to show that the wife sees the effect the intimacy is having on the husband as the clench almost turns into a moment of holding hands. Rather than reconcile at this moment, however, Fontanne sends the confrontation into another unit of action. To show that the wife takes control, Fontanne dismissively pushes Lunt's hand (and the knife) away, telling the husband to be more careful. In response, Lunt brings the knife to his side, the picture of a defeated man.

A wide shot shows Lunt kneeling at Fontanne's side as she sits back comfortably in her chair. Asserting her complete victory, 
the wife complains that her husband had been so preoccupied with his performance that he could not imagine that she had also turned in a great performance. This new subject prompts the husband to fight back; he is not going to let his wife lay claim to being the better actor. Lunt stands quickly and the husband declares that his wife is lying. The husband's demand brings the confrontation to a head: Lunt and Fontanne (seem to) speak simultaneously as words and phrases dovetail seamlessly. The husband insists that he could not be recognized; the wife insists that she did recognize him. Rather than creating distance, however, their debate re-establishes the warm collegial rivalry between the acting partners and the intimate connection between the couple. Lunt and Fontanne communicate that warmth by using more melodic vocal intonations and by adopting more relaxed, free-flowing physical gestures.

With the husband's concerns about his wife's infidelity put to rest, the difficult stages of the characters' confrontation come to an end; their friendly debate is interrupted by the entrance of a bill collector, who immediately recognizes the husband and greets him without hesitation. After he exits, Fontanne takes the lead in the scene's final unit of action. To soften the blow to her husband's ego caused by the fact that, in this round, the wife has proved the better actor, she coyly tells him that his wonderful lovemaking gave him away when she invited him, as the Russian officer, to spend the night with her. Lunt offers only little resistance to this piece of news, and so sustains his character's amusing internal struggle between personal and professional satisfaction.

In this scene, Lunt and Fontanne have orchestrated their performances so that neither of the characters or actors dominates the scene. There are no melodramatic postures or poses. Instead, both performances seem entirely natural because they consist of small realistic details that communicate both the characters' stubborn opposition and their intellectual, emotional and physical intimacy. In addition, the actors' exhaustive script analysis and private rehearsal has made it possible for them to craft performances that direct audience attention to the characters' interlocking series of actions. Importantly, by crafting their performances to communicate the characters' given circumstances, 
objectives and dramatic actions, Lunt and Fontanne create a scene that has elegant structure, clear logic and engaging forward momentum.

The ostensibly spontaneous but in fact rigorously crafted performances of Lunt and Fontanne would provide a model for a generation of stage and screen actors. Barbara Stanwyck, who appeared in Broadway productions such as Keep Kool (1924), The Noose (1926-27), and Burlesque (1927-28) before moving to Hollywood, is one of many actors who studied the Lunts' work. For example, fellow actor Robert Preston explains that when he appeared with Stanwyck in Union Pacific (Cecil B. DeMille, 1939), she used the Lunts' performances as a model for what constituted a realistic portrayal of intimacy. As he recalls, during a rehearsal Stanwyck pulled him toward her, pressed her body against his and said, "The difference between Lunt and Fontanne and the leads in a high school play is just as simple as this" (Tomlinson 1994, p. 447). Her comment reflects the fact that audiences, critics and acting professionals of the period recognized that the naturalism of the Lunts' performances included realistic moments of physical intimacy. Describing their performances, one critic highlighted "that peculiar alternation of frank physical passion and raucous amusement at it which is practically their trademark in the theatre" (Peters 2003, p. 221).

\section{Conclusion}

Given the changing fortunes of Broadway and Hollywood, stage actors and modern methods for building performances became part of industrial sound cinema production in the 1930s. These methods were integral to the era's performances in theatre and film - and for performances by some actors mistakenly associated with Lee Strasberg's formulation of the Method. For example, Montgomery Clift, who has been seen as exemplifying Method acting, first appeared on Broadway in 1935 at the age of 14, and was later cast by Alfred Lunt as the idealistic resistance fighter in There Shall Be No Night (1939-42). During the two and a half years of the production's tour, Clift learned his craft from the Lunts. He credits Alfred Lunt with "his development as an actor," because Lunt illustrated "the artist's 
dedication to the craft" and showed Clift how to build performances through the "accumulation of subtle details" suggested by thorough script analysis and tested in rehearsal (Bosworth 2007, pp. 83-84; see p. 101).

The shared methods behind performances of stage-trained actors working in theatre and film reflect the era's business realities after the coming of sound led Hollywood to overtake Broadway as America's primary provider of commercial dramatic art. Even during Broadway's peak in 1927-28, "promising young players" were being signed to Hollywood film contracts "before they ever achieved Broadway stardom" (Blum 1950, pp. 183, 189). Moreover, whereas Hollywood had worked to compete with theatre and radio in the early 1920s, sound cinema became so "popular that the weekly attendance at movie houses rose from sixty-five million in 1927 to ninety million by the end of 1929," and Hollywood was producing more than 400 films a year by the end of the 1930s (Wilson 1973, p. 398; Watermeier 1999, p. 482).

Sound cinema's success meant that many actors cast in Broadway productions in the 1920s were working in film in the 1930s. The migration from Broadway to Hollywood created the unusual situation where theatre stars such as Alfred Lunt and Lynn Fontanne exemplified modern acting for performers working in film. The ostensive break between many film actors' formative years in theatre and their subsequent years as film stars also seems to have created a rupture in histories of acting, causing teachers such as Jehlinger at the American Academy of Dramatic Arts to be "unknown outside of theatrical circles," despite the perception that he was "the most outstanding teacher of acting in the twentieth century" (anonymous 1952). There is, arguably, much to be gained by looking at developments in the 1930s from the perspective of (stage-trained) actors striving to work in a business undergoing profound industrial change and inspired by the many acting teachers whose efforts contributed to the circulation and articulation of modern acting methods and principles.

Bowling Green State University 


\section{NOTES}

1. See http://www.playbillvault.com/Seasons/.

2. It is difficult to determine when the generic but suggestive term "modern acting" came into circulation in the United States. By the mid-1930s, it seems to have become the accepted term for referring to the acting methods and principles formulated during the landmark period of development from roughly 1890 to 1920 . For example, the term is taken as a given and never specifically defined in the Samuel French publication Modern Acting: A Manual by Sophie Rosenstein, Larrae A. Haydon and Wilbur Sparrow (1936). The requirements that actors immerse themselves in their characters and focus on characters' interactions rather than the audience are key principles of modern acting. The Academy of Dramatic Arts in New York solved the problem of how actors could think, feel and act as their characters "by introducing the 'Magic If' long before the phrase was popularized by Stanislavsky" (McTeague 1993, p. 54). In addition, by requiring actors to "concentrate on the character in the "lifelike' situation of the play" and see the audience as "an unobtrusive onlooker," the Academy anticipated Stanislavsky's emphasis on the idea of "public solitude" (p. 56).

3. For the author's other work that discusses acting methods in the 1930s, as well as contrasts between modern acting and the version of Method acting popularized by Lee Strasberg during his time at the Actors Studio, see Baron 1998, Baron 1999, Baron and Carnicke 2008 (especially pp. 24-28), and Baron and Warren 2012.

4. Publications that place the Actors Studio at the centre of histories of American acting include David Garfield's The Actors Studio: A Player's Place (1984), Foster Hirsh's A Method to Their Madness: The History of the Actors Studio (2001) and Steve Vineberg's Method Actors: Three Generations of an American Acting Tradition (1994). Subsequent scholarship has deconstructed various aspects of these accounts; this work includes David Krasner's anthology Method Acting Reconsidered: Theory, Practice, Future (2000) and most especially Sharon Marie Carnicke's Stanislavsky in Focus, 2nd edition (2009).

5. Acting methods taught at the American Academy of Dramatic Arts in its earliest years are covered in a 1970 dissertation by Mark Jerome Malinauskas, "The American Academy of the Dramatic Arts: A History (1884-1897)."

6. Revisions to the Academy's training program reflect perspectives articulated in a 1912 New York Times article entitled "Arliss on the Actor's Calling" and a 1915 New York Times article entitled "Barker on Stanislofsky." Both concern speeches made at the Academy about acting methods that foster performances distinguished by a sense of "truth and sincerity" (anonymous 1912); the 1915 article notes that when actors establish "milestones" [objectives] for individual scenes prior to performances, their interactions with other actors will be "really spontaneous."

7. It is important to note that Tracy's training in pantomime did not involve learning specific, codified gestures or facial expressions to convey emotions. Instead, when a student worked on pantomime exercise, he or she would concentrate on "the emotion which causes the action" (anonymous 1899, p. 25). Given that emphasis, the method is comparable to what Stanislavsky saw as the method of physical actions, where performances can be approached from the outside in, with the character's thoughts and feelings accessed by rehearsing the sequence of physical actions in a scene (Carnicke 2000, pp. 26-27). The focus on connections between emotion and physical expression also informs acting methods grounded in Laban's Movement Analysis (Baron 2006) and Alba's Emoting (Barton 2006, pp. 299-302).

8. That observation, of course, is quite different from the remark often attributed to Tracy that acting involves little more than three things: "Show up on time, know your lines, and don't bump into the furniture" (Bailey 2013). One might note that 
Tracy's joke parallels a rather pointed dismissal of the seriousness purportedly found only in the work of players associated with the Actors Studio; speaking to the Gallery First Nighters' Dinner in 1962, Noël Coward quipped: "You ask my advice about acting? Speak clearly, don't bump into the furniture and if you must have motivation, think of your pay packet on Friday" (Payn 2000, p. 283).

9. The website of the Ten Chimneys Foundation, which maintains the estate of Alfred Lunt and Lynn Fontanne, briefly discusses their preference for working in live theatre. To describe their lack of interest in film work, it explains: in 1932 "one studio offered the Lunts $\$ 1,000,000$ for a two-film deal. Fontanne was reported to tell the studio head, 'My dear sir, we can be bought, but we cannot be bored." See http:// www.tenchimneys.org/about/about-lynn-alfred.

\section{BIBLIOGRAPHICAL REFERENCES}

Albertson 1947: Lillian Albertson, Motion Picture Acting, New York, Funk and Wagnalls, 1947, $135 \mathrm{p}$.

Anonymous 1899: anonymous, Annual Catalogue of the American Academy of Dramatic Arts 1899, New York, American Academy of Dramatic Arts, 1899, n.p.

Anonymous 1912: anonymous, "Arliss on the Actor's Calling," New York Times, March 24, 1912.

Anonymous 1915: anonymous, "Barker on Stanislofsky," New York Times, March 21, 1915.

Anonymous 1952: anonymous, "Jehlinger is Dead; Teacher of Actors: Dean of American Academy of Dramatic Arts Had Developed Many Stage, Film Stars," New York Times, July 30, 1952.

Bailey 2013: Jason Bailey, “The Perfect Idiot's Profession': When Famous Actors Ridicule Their Craft," The Atlantic, January 7, 2013.

Baron 1998: Cynthia Baron, "The Method Moment: Situating the Rise of Method Acting in the 1950s," Popular Culture Review, Vol. 9, no. 2, 1998, pp. 89-106.

Baron 1999: Cynthia Baron, "Crafting Film Performances: Acting in the Hollywood Studio Era," in Alan Lovell and Peter Krämer (eds.), Screen Acting, New York, Routledge, 1999, pp. 31-45.

Baron 2006: Cynthia Baron, "Performance in Adaptation: Human Movement in Motion Pictures," Cineaste, Vol. 31, no. 4, 2006, pp. 48-55.

Baron and Carnicke 2008: Cynthia Baron and Sharon Marie Carnicke, Reframing Screen Performance, Ann Arbor, University of Michigan Press, 2008, 301 p.

Baron and Warren 2012: Cynthia Baron and Beckett Warren, "The Actors Studio in the Early Cold War," in Cynthia Lucia, Roy Grumman and Art Simon (eds.), The Wiley-Blackwell History of American Film, Volume III, 1946-1975, Malden, WileyBlackwell, 2012, pp. 137-57.

Barton 2006: Robert Barton, Acting Onstage and Off, 4th edition, Belmont, Thompson Wadsworth, 2006, $374 \mathrm{p}$.

Blum 1950: Daniel Blum, A Pictorial History of the American Theatre 1900-1950, New York, Greenberg, 1950, 288 p.

Boleslavsky 1933: Richard Boleslavsky, Acting: The First Six Lessons, New York, Theatre Arts Books, 1933, 122 p.

Bordwell, Staiger and Thompson 1985: David Bordwell, Janet Staiger and Kristin Thompson, The Classical Hollywood Cinema: Film Style and Mode of Production to 1960, New York, Columbia University Press, 1985, 506 p. 
Bosworth 2007: Patricia Bosworth, Montgomery Clift: A Biography, New York, Limelight, 2007, 438 p.

Brown 1943: Gilmor Brown and Alice Garwood, General Principles of Play Direction, New York and Los Angeles, Samuel French, 1943, s. n.

Brown 1986: Jared Brown, The Fabulous Lunts: A Biography of Alfred Lunt and Lynn Fontanne, New York, Atheneum, 1986, 523 p.

Carnicke 2000: Sharon Marie Carnicke, "Stanislavsky's System: Pathways for the Actor," in Alison Hodge (ed.), Twentieth Century Actor Training, London and New York, Routledge, 2000, pp. 11-36.

Carnicke 2009: Sharon Marie Carnicke, Stanislavsky in Focus, 2nd edition, London and New York, Routledge, 2009, 252 p.

Clark 1995: Danae Clark, Negotiating Hollywood: The Cultural Politics of Actors' Labor, Minneapolis, University of Minnesota Press, 1995, 168 p.

Cronyn 1949: Hume Cronyn, "Notes on Film Acting," Theatre Arts, Vol. 35, June 1949, pp. 45-48.

Curtis 2011: James Curtis, Spencer Tracy: A Biography, New York, Knopf, 2011, $1024 \mathrm{p}$.

Davis 1946: Bette Davis, "On Acting in Films," Theatre Arts, Vol. 25, September 1946, pp. 633-39.

Dillon 1940: Josephine Dillon (Gable), Modern Acting: A Guide for Stage, Screen and Radio, New York, Prentice-Hall, 1940, 313 p.

Funke and Booth 1961: Lewis Funke and John E. Booth, Actors Talk about Acting, London, Thames and Hudson, 1961, 281 p.

Garfield 1984: David Garfield, The Actors Studio: A Player's Place, New York, Macmillan, 1984, 318 p.

Geraghty 2000: Christine Geraghty, "Re-examining Stardom: Questions of Texts, Bodies, and Performance," in Christine Gledhill and Linda Williams (eds.), Reinventing Film Studies, London, Arnold, 2000, pp. 183-201.

Gould 1958: Eleanor Cody Gould, Charles Jehlinger in Rehearsal (pamphlet), New York, American Academy of Dramatic Arts, 1958, n.p.

Hirsh 2001: Foster Hirsh, A Method to Their Madness: The History of the Actors Studio, New York, Da Capo, 2001, 368 p.

Klumph 1922: Inez and Helen Klumph, Screen Acting: Its Requirements and Rewards, New York, Falk Publishing, 1922, 243 p.

Krasner 2000: David Krasner, "I Hate Strasberg; Method Bashing in the Academy," in David Krasner (ed.), Method Acting Reconsidered, New York, St Martin's Press, 2000, pp. 3-39.

Malinauskas 1970: Mark Jerome Malinauskas, "The American Academy of the Dramatic Arts: A History (1884-1897)," Ph.D. dissertation, University of Oregon, 1970.

McTeague 1993: James H. McTeague, Before Stanislavsky: American Professional Acting Schools and Acting Theory 1875-1925, Metuchen, Scarecrow, 1993, 296 p.

Payn 2000: Graham Payn, My Life with Noël Coward, New York, Applause, 2000, $404 \mathrm{p}$.

Peters 2003: Margot Peters, Design for Living: Alfred Lunt and Lynn Fontanne, New York, Knopf, 2003, 416 p.

Raymond 2009: Gerard Raymond, " 125 Years and Counting: The American Academy of Dramatic Arts Celebrates a Special Anniversary," Backstage, November 26-December 2, 2009, pp. 6-7. 
Rosenstein, Haydon and Sparrow 1936: Sophie Rosenstein, Larrae A. Haydon and Wilbur Sparrow, Modern Acting: A Manual, New York and Los Angeles, Samuel French, 1936, 129 p.

Sargent 1884: Franklin H. Sargent, "Conservatoire, Shall We Have One?," Century Magazine, no. 6, July 1884, p. 475.

Schatz 2010: Thomas Schatz, The Genius of the System: Hollywood Filmmaking in the Studio Era, Minneapolis, University of Minnesota Press, 2010, 528 p.

Tomlinson 1994: Doug Tomlinson (ed.), Actors on Acting for the Screen, New York, Garland, 1994, 689 p.

Vineberg 1994: Steve Vineberg, Method Actors: Three Generations of an American Acting Tradition, New York, Shirmer, 1994, 364 p.

Watermeier 1999: Daniel J. Watermeier, "Actors and Acting," in Don B. Wilmeth and Christopher Bigsby (eds.), The Cambridge History of American Theatre, Volume II, 1870-1945, New York, Cambridge University Press, 1999, pp. 446-86.

Wilson 1973: Garff B. Wilson, Three Hundred Years of American Drama and Theatre, Englewood Cliffs, Prentice-Hall, 1973, 536 p.

Wilson 2013: Victoria Wilson, A Life of Barbara Stanwyck: Steel-True 1907-1940, New York, Simon and Schuster, 2013, 1056 p.

\section{RÉSUMÉ}

\section{L'arrivée à Hollywood, dans les années 1930, des acteurs de théâtre et des techniques de jeu modernes Cynthia Baron}

Dans cet article, l'auteure s'intéresse aux facteurs qui, dans les années 1930 aux États-Unis, ont amené de nombreux acteurs issus du théâtre à livrer, sur la scène aussi bien qu'à l'écran, des performances basées sur les principes du jeu théâtral moderne (articulés par Stanislavski, enseignés à l'American Academy of Dramatic Arts de New York ou décrits dans les manuels d'art dramatique) pour s'adapter à l'arrivée du parlant, puis à l'industrialisation du cinéma sonore, qui ont profondément bouleversé les perspectives d'emploi à Broadway et les méthodes de production à Hollywood. Pour illustrer certains aspects de la conception que les acteurs formés aux arts de la scène se faisaient du jeu moderne à cette époque exceptionnelle de l'histoire américaine des arts du spectacle, l'auteure analyse une scène jouée par Spencer Tracy dans Captains Courageous (Capitaines courageux, Victor Fleming, 1937) et une scène du film The Guardsman (L'officier de la garde, Sidney Franklin, 1931) interprétée par Alfred Lunt et Lynn Fontanne. 